\title{
Sadeyağ üretiminde kullanılan süt, yoğurt ve kremanın gıda güvenliği açısından değerlendirilmesi
}

\author{
Evaluation of milk, yogurt and cream used in the production of sadeyag in terms of food \\ safety
}

\author{
Mehmet Şükrü KARAKUŞ ${ }^{*^{*} \text { iD }}$, Zahide POLAT ${ }^{2}$ iD, Sevda KAMACl ${ }^{3}$ iD Ahmet Ferit ATASOY $^{4}$ iD \\ 1*100/2000 YÖK Doktora Programı, Gıda Güvenliği ve Gıda Güvencesi, Harran Üniversitesi \\ 1,2,3,4 Harran Üniversitesi, Mühendislik Fakültesi Gıda Mühendisliği Bölümü, Osmanbey Kampüsü, Haliliye-Şanlıurfa
}

${ }^{1}$ https://orcid.org/0000-0002-1805-8206; ${ }^{2}$ https://orcid.org/0000-0001-6622-446X;

${ }^{3}$ https://orcid.org/0000-0001-9543-0983; ${ }^{4}$ https://orcid.org/0000-0002-3390-1177

\section{To cite this article:}

Karakuş, M.Ş, Polat, Z., Kamacl, S. \& Atasoy, A.F. (2021). Sadeyağ üretiminde kullanılan süt, yoğurt ve kremanın gıda güvenliği açısından değerlendirilmesi. Harran Tarım ve Gıda Bilimleri Dergisi, 25(4): 546555.

DOI: $10.29050 /$ harranziraat. 984787

\section{*Address for Correspondence: Mehmet Şükrü KARAKUŞ e-mail:}

sukrukarakus@harran.edu.tr

Received Date:

19.08.2021

Accepted Date:

20.09.2021

(C) Copyright 2018 by Harran University Faculty of Agriculture. Available on-line at www.dergipark.gov.tr/harranziraat
Öz

Bu çalışmada, farklı türlere ait süt (koyun ve inek), yoğurt (koyun ve inek) ve kremaların (inek ve koyun; çiğ, olgunlaştırılmış ve pastörize krema) bazı fizikokimyasal ve mikrobiyolojik özellikleri araştırılmıştır. Koyun sütünün inek sütünden daha fazla yağ, protein ve mineral madde içeriğine sahip olduğu belirlenmiştir $(\mathrm{P}<0.05)$. Koyun ve inek $\mathrm{pH}$ değerleri arasındaki fark önemsizken $(P>0.05)$, koyun sütü titrasyon asitliği inek sütünden daha yüksek bulunmuştur $(P<0.05)$. İnek yoğurdu kurumadde, yağ oranı ve titrasyon asitliği değeri koyun yoğurdundan daha düşük $(P<0.05), \mathrm{pH}$ değerlerinin ise farklı olmadığı belirlenmiştir $(P>0.05)$. Koyun sütünden elde edilen kremaların kuru madde ve yağ değerlerinin inek sütünden elde edilen kremalardan daha yüksek olduğu $(\mathrm{P}<0.001)$, $\mathrm{pH}$ ve titrasyon asitliği değerlerinin aynı olduğu belirlenmiştir $(P>0.05)$. En yüksek $\mathrm{pH}$ ve en düşük titrasyon asitliği değerleri çiğ kremada tespit edilmiştir $(P<0.001)$. Olgunlaştırılmış kremalara ait E.coli ve Koliform bakteri sayılarının çiğ süt ve çiğ kremalardan daha yüksek olduğu belirlenmiştir. Yoğurt ve pastörize kremalarda E.coli ve Koliform bakteriler bulunmamıştır. Sonuç olarak bu çalışmada kullanılan süt, yoğurt ve kremaların Türk Gıda Kodeksi Tebliği'ne uygun olduğu ve sadeyağ üretiminde kullanılan yoğurt ve pastörize kremaların Gıda Güvenliği 'ne uygunluğu belirlenmiştir.

Anahtar Kelimeler: Gıda güvenliği, Sadeyağ, Tereyağı, Koyun yoğurdu, Krema

\section{ABSTRACT}

In this study, some physicochemical and microbiological properties of different types of milk (sheep and cow), yoghurts (sheep and cow) and creams (raw cream, ripened and pasteurized cream) were determined. Ovine milk had higher fat, protein and mineral content than cow's milk $(P<0.05)$. The difference between the $\mathrm{pH}$ values of sheep and cows was insignificant $(P>0.05)$, and the titration acidity of sheep milk was higher than that of cow milk. Although cow yoghurt's dry matter, fat content and titration acidity values were lower $(P<0.05)$ than sheep yoghurt, $\mathrm{pH}$ values were found to be insignificant $(P>0.05$. The values of dry matter and fat contents the creams obtained from sheep milk were higher than cow milk $(P<0.001)$, the $\mathrm{pH}$ and titration acidity values were determined same $(\mathrm{P}>0.05)$. The highest $\mathrm{pH}$ and lowest titration acidity levels were determined in raw cream $(P<0.001)$. E.coli and Coliform bacteria count of ripened creams were higher than raw milk and raw creams. E.coli and Coliform bacteria were not found in yoghurt and pasteurized creams. As a result, it has been determined that the milk, yogurt and cream used in this study comply with the Turkish Food Codex Communiqué and that the yogurt and pasteurized creams used in clarified butter production are suitable for Food Safety.

Key Words: Food safety, Sadeyag, Butter, Ovine yoghurt, Cream 
Giriş

Sadeyağ; süt ve/veya süt ürünlerinden elde edilen su ve yağsız kurumadde bileşenlerinin tamamına yakını uzaklaştırımış ağırlıkça en az 99 gr/100 gr süt yağı içeren bir üründür (Anonim, 2005; Yokuş ve ark., 2019). Türkiye'de sadeyağ olarak adlandırılan bu ürün Şanlıurfa ilinde Şanlıurfa Yağı (Urfa Yağı) olarak bilinmektedir ve 2018 yılında coğrafi işaretli ürünler listesine alınmıştır (Anonim, 2018). Şanlıurfa'da sadeyă̆ üretimi, koyun yoğurdundan elde edilen tereyağının düşük sıcaklıklarda eritilmesiyle yapılmaktadır. Sadeyağın hammaddesi olan tereyağı ağırlıkça en az \%80 en fazla \%90 süt yağı, en fazla \%16 su ve $\% 2$ yağsız süt kuru maddesine sahip ürün olarak tanımlanmıştır (Anonim, 2005).

Gıda güvenliği; bir ürünün üretim aşamasında gerekli tüm kontrolleri yapmak, gıdalarda oluşabilecek fiziksel, kimyasal veya biyolojik tehlike unsurlarını engellemek ve insan sağ ı̆̆ını korumaya yönelik bir sistemdir (Paçacı, 2019). Süt, patojenik mikroorganizmaların gelişmesi için ideal bir gıdadır. Çiğ süt tüketimi, kimyasal bileşimi nedeniyle gıda kaynaklı hastalıklar için iyi tanımlanmış bir risk faktörüdür. Ancak pastörizasyon, süt ürünlerinin güvenliğini sağlamada oldukça etkili bir yöntemdir. Isıl işlemler (örneğin pastörizasyon, ultra yüksek sıcaklık, haşlama sıcaklıkları) veya sıcaklık kontrolü (soğutma ve dondurma), son ürünün fiziksel, kimyasal ve mikrobiyolojik özelliklerinin güvenli hale getirilmesi amacıyla kritik bir nokta olarak kabul edilmektedir. Pastörizasyon, klasik zoonozları, örneğin Brucella'yı ve ayrıca E.coli, Koliform bakteri gruplarını kontrol etmek amacıyla uygulanmaktadır (Van Schothorst and Kleiss, 1994). Yoğurt, krema ve tereyağı gibi ürünlerin hammaddesi süttür. Farklı tür hayvanlara ait çiğ süt; yoğurt, krema, tereyağı ve diğer süt ürünleri üretiminin temelini oluşturmaktadır. Ayrıca çiğ sütün kalitesinin kodekste belirtilen kriterlerle uyumlu olması yasal bir zorunluluktur ve üretilecek ürünün kalitesini de olumlu yönde etkilemektedir (Ali ve Fischer, 2005). Çiğ sütün kalitesinin standartlara uygun olmaması, uygun pastörizasyon normlarının uygulanmaması gıda güvenliği açısından sorun teşkil etmektedir.

Bu çalışmada, Şanlıurfa ilinde geleneksel yöntemle üretilen Sadeyağ (Urfa Yağı) yapımında kullanılan süt, yoğurt ve kremalara ait fizikokimyasal ve mikrobiyolojik özelliklerin belirlenerek gıda güvenliği açısından irdelenmesi amaçlanmıştır.

\section{Materyal ve Metot}

\section{Materyal}

Bu çalışmada kullanılan inek ve koyun sütleri, Kevser Süt Ürünlerinden (Şanlıurfa, Türkiye) klarifike edilmiş (REDA S.p.A Klarifikatör, Vicenza, Italy) halde temin edilmiştir. Üretimde starter kültür olarak YC-350 (Lactobacillus delbrueckii subsp. bulgaricus ve Streptococcus thermophilus) (Chr. Hansen, PeymaHansen, Türkiye) liyofilize yoğurt kültürü kullanılmıştır.

\section{Yöntem}

Koyun ve inek sütünden üretilen yoğurt ve krema üretim akış şeması Şekil 1.' de gösterilmiştir. Üretimler Harran Üniversitesi Mühendislik Fakültesi Gıda Mühendisliği Bölüm Laboratuvarında gerçekleştirilmiştir.

\section{Koyun ve inek sütü yoğurtlarının üretimi}

Klarifike edilmiş çiğ koyun ve inek sütlerine $85 \pm 2$ ${ }^{\circ} C^{\prime}$ de 20 dakika ısıl işlem uygulandıktan sonra sütler hemen $44 \pm 1{ }^{\circ} C^{\prime}$ ye soğutulmuştur. Daha sonra, soğutulan sütlere $\% 2$ oranında starter kültür ilave edilerek $44 \pm 1{ }^{\circ} C^{\prime}$ de inkübasyona alınmış ve $\mathrm{pH} 4.60 \pm 0.05^{\prime}$ da inkübasyona son verilmiştir. Elde edilen yoğurtlar hızlı bir şekilde $10 \pm 2{ }^{\circ} C^{\prime}$ ye soğutulmuş ve olgunlaşması için $4 \pm 1{ }^{\circ} \mathrm{C}^{\prime}$ de 24 saat bekletilmiştir. Üretilen yoğurtlar 24 saat sonra yayıklama işlemine tabi tutulmuşlardır. Çalışma 3 tekerrürlü olarak yürütülmüştür.

\section{Koyun ve inek kremalarının elde edilmesi}

Klarifike edilmiş koyun ve inek sütlerine $45 \pm 2$ ${ }^{\circ} \mathrm{C}$ 'de 10 dakika ön ısıtma işlemi uygulandıktan sonra seperatörden (Asya Zenit, Kayseri) geçirilmiş, krema ve yağsız süt elde edilmiştir. Elde 
edilen çiğ krema $\% 37 \pm 2$ yağ oranına ayarlandıktan sonra kültür ilave edilmeden pH: $5.35 \pm 0.05$ 'e kadar olgunlaştırılmıştır. Olgunlaştırılan kremaya $85 \pm 2$ ${ }^{\circ} \mathrm{C}$ 'de 20 dakika ısıl işlem uygulandıktan sonra hızlıca $10 \pm 2{ }^{\circ} C^{\prime}$ ye soğutulmuş, $4 \pm 1{ }^{\circ} C^{\prime}$ de 24 saat bekletilmiştir. Daha sonra elde edilen pastörize kremalar yayıklama işlemine tabi tutulmuşlardır. Çalışma 3 tekerrürlü olarak yürütülmüştür.

Klarifike edilmiş çiğ süt

(Koyun ve inek)

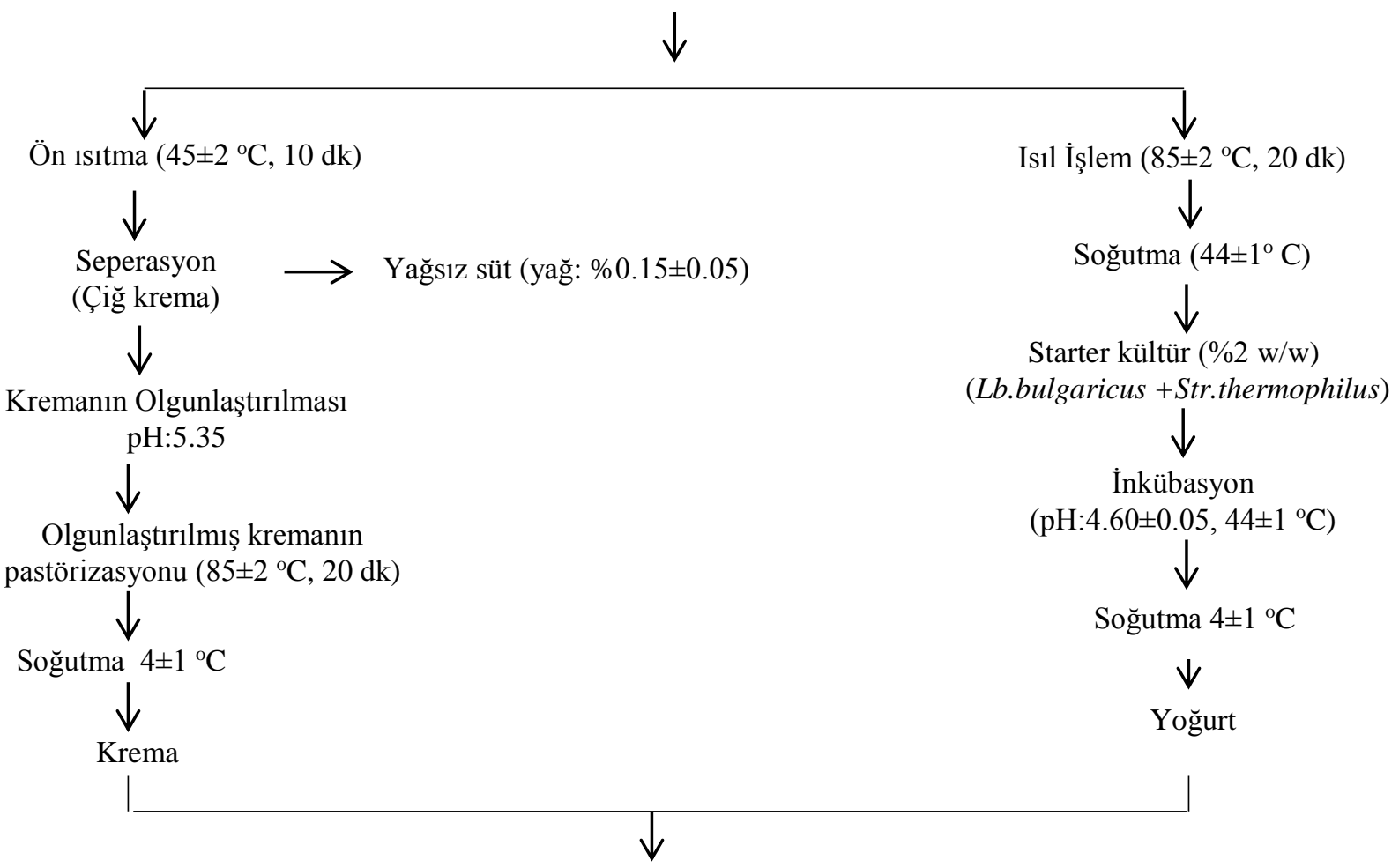

Su ilavesi (Krema, yoğurt: su, 1:1)

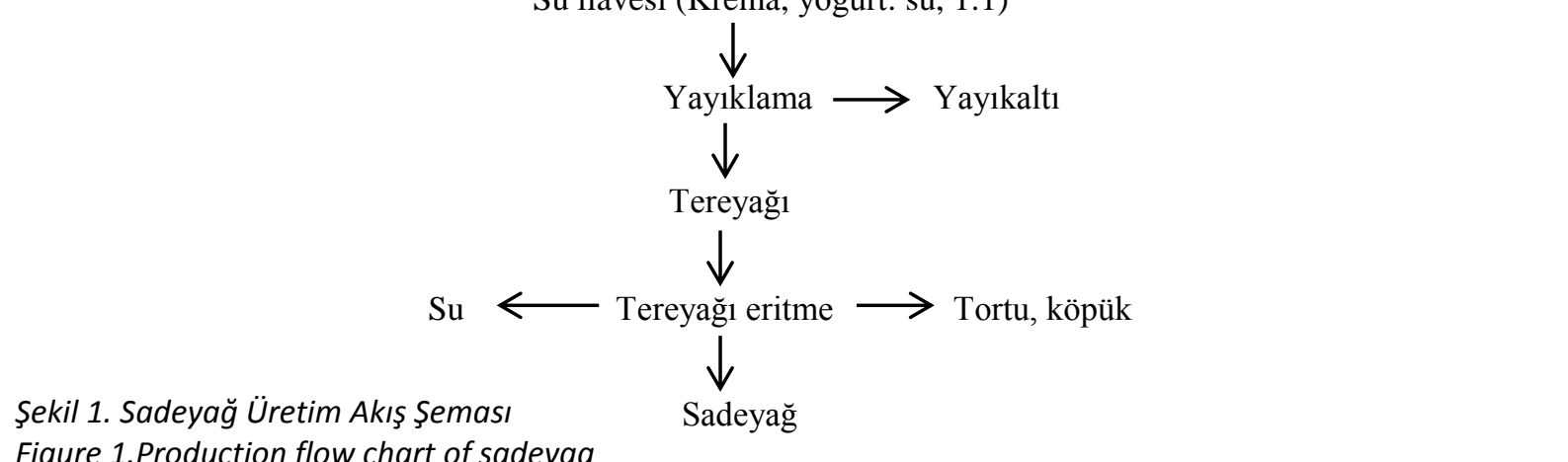

\section{Kimyasal analizler}

Koyun ve inek sütlerine ait kurumadde, yağ ve protein miktarları süt analiz cihazı (Milkana Superior) kullanılarak belirlenmiştir. Çiğ sütlerin kül değerleri gravimetrik yöntemle (Yıldız Akgül ve ark., 2018) tespit edilmiştir. Süt, yoğurt ve kremaya ait asitlik tayini \% laktik asit cinsinden titrasyon yöntemiyle, $\mathrm{pH}$ değerleri $\mathrm{pH}$ metreyle (OHAUS Starter 3100, USA) (Şanlıdere Aloğlu, 2018), yoğurt ve kremaya ait kurumadde değerleri gravimetrik yöntemle (Yıldız Akgül ve ark., 2018), yağ tayini gerber metoduyla belirlenmiştir.

\section{Mikrobiyolojik analizler}

Süt, yoğurt ve krema örneklerinin mikrobiyolojik analizleri kültürel sayım yöntemleri kullanılarak yapılmıştır (Halkman, 2005). Koliform grubu mikroorganizmalar Violet Red Bile Agar (VRBA) besiyerine ekim yapılmış ve $37{ }^{\circ} C^{\prime}$ de 24 saat inkübasyon sonucu oluşan kırmızı renkli koloniler sayılmıştır. E.coli için ise Chromocult TBX agar besiyerine ekim yapılmış ve $44{ }^{\circ} C^{\prime}$ de 24 saat inkübasyona tabi tutulmuş ve inkübasyon sonunda mavi-yeşil renkli koloniler sayılmıştır. 
Istatistiksel analizler

İstatistiksel analizler SPSS (Version 16.0, Chicago, IL, U.S.A.) paket programı kullanılarak yapılmıştır. Gruplar arasındaki farklılıkların belirlenmesinde DUNCAN çoklu karşılaştırma testi tek yönlü Anova uygulanmıştır.

\section{Araştırma Bulguları ve Tartışma}

Koyun ve inek sütlerine ait bileşimler Tablo 1'de gösterilmiştir. Koyun sütü toplam kuru madde, yağ, protein, kül, titrasyon asitliği değerleri inek sütünden yüksek bulunmuştur $(P<0.05)$. Laktoz ve $\mathrm{pH}$ değerlerinin ise aynı olduğu tespit edilmiştir $(P>0.05)$. Sütün bileşimi hayvanın cinsine, ırka, mevsime, besleme ve yönetim koşullarına, çevresel koşullara, bölgeye ve laktasyon dönemine göre değişiklik gösterebilmektedir (Haenlein, 2001; Pulina et al., 2006). Koyun ve inek sütlerinin E.coli sayısının sırasıyla $4.67 \mathrm{log}$ kob/g ve $5.22 \mathrm{log}$ kob/g, Koliform bakteri sayısının ise $5.99 \mathrm{log}$ kob/g ve 6.05 log kob/g arasında olduğu saptanmıştır. İnek sütüne ait E.coli sayısının koyun sütünden yüksek $(P<0.05)$, Koliform bakteri sayılarının ise istatistiksel olarak aynı olduğu belirlenmiştir (P>0.05). Türk Gıda Kodeksi Çiğ Süt Tebliği'ne $(2019 / 12)$ göre koyun ve inek sütlerinin protein, yağsız kuru madde, süt yağı, asitlik değeri sırasıyla en az \%3.1, \%2.8; \%10.0, \%8.5; \%6.0, \%3.4; \%0.16$\% 0.35 ; \% 0.135-\% 0.20$ olması gerektiği bildirilmiştir (Anonim, 2019b). Bu çalışmada kullanılan koyun ve inek sütüne ait fizikokimyasal özelliklerin önceki çalışmalar ve kodekse uygun olduğu belirlenmiştir. Ayrıca çiğ sütün sınıflandırılmasına ait tebliğde (2019/64), çiğ inek sütünün bileşimindeki yağ ve protein oranının A sınıfı kategorisi için sırasıyla en az \%3.10 ve \%3.50 olması gerektiği belirtilmiştir. Bu çalışmada kullanılan çiğ inek sütü $A$ sınıf kategorisinde yer aldığı tespit edilmiştir (Anonim, 2019a).

Çizelge 1. Koyun ve inek sütü bileşimleri

Table 1. Sheep and cow milk compositions

\begin{tabular}{|c|c|c|}
\hline $\begin{array}{l}\text { Analizler } \\
\text { Analyzes }\end{array}$ & $\begin{array}{l}\text { Koyun } \\
\text { Sheep }\end{array}$ & $\begin{array}{l}\text { İnek } \\
\text { Cow }\end{array}$ \\
\hline $\begin{array}{l}\text { Kurumadde }\left({\left.\mathrm{g} 100 \mathrm{~g}^{-1}\right)}\right. \\
\text { Dry matter }\left(\mathrm{g} 100 \mathrm{~g}^{-1}\right)\end{array}$ & $17.69 \pm 0.19^{a}$ & $12.27 \pm 0.06^{b}$ \\
\hline $\begin{array}{l}\text { Yağ oranı }\left(\mathrm{g} 100 \mathrm{~g}^{-1}\right) \\
\text { Fat content }\left({\left.\mathrm{g} 100 \mathrm{~g}^{-1}\right)}\right.\end{array}$ & $6.95 \pm 0.05^{a}$ & $3.65 \pm 0.03^{b}$ \\
\hline $\begin{array}{l}\text { Protein }\left({\left.\mathrm{g} 100 \mathrm{~g}^{-1}\right)}^{\text {Protein }\left(\mathrm{g} 100 \mathrm{~g}^{-1}\right)}\right.\end{array}$ & $5.24 \pm 0.01^{a}$ & $3.30 \pm 0.02^{b}$ \\
\hline 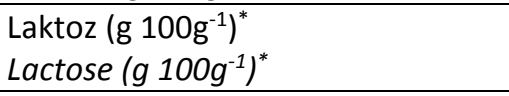 & $4.62 \pm 0.21^{\mathrm{a}}$ & $4.61 \pm 0.01^{a}$ \\
\hline $\begin{array}{l}\text { Kül }\left({\left.\mathrm{g} 100 \mathrm{~g}^{-1}\right)}\right. \\
\text { Ash }\left(\mathrm{g} 100 \mathrm{~g}^{-1}\right)\end{array}$ & $0.88 \pm 0.02^{a}$ & $0.72 \pm 0.02^{b}$ \\
\hline $\begin{array}{l}\mathrm{pH} \\
\mathrm{pH}\end{array}$ & $6.72 \pm 0.02^{a}$ & $6.62 \pm 0.04^{a}$ \\
\hline $\begin{array}{l}\text { Titrasyon asitliği (\% laktik asit) } \\
\text { Titratable acidity (lactic acid \%) }\end{array}$ & $0.21 \pm 0.00^{a}$ & $0.17 \pm 0.00^{b}$ \\
\hline $\begin{array}{l}\text { Escherichia coli }\left(\log \mathrm{kob}^{-1}\right) \\
\text { Escherichia coli }\left(\log \mathrm{cfu} \mathrm{fu}^{-1}\right)\end{array}$ & $4.67 \pm 0.02^{b}$ & $5.22 \pm 0.01^{\mathrm{a}}$ \\
\hline $\begin{array}{l}\text { Koliform bakteri }\left(\log \mathrm{kob} \mathrm{g}^{-1}\right) \\
\text { Coliform bacteria }\left(\log \mathrm{cfu} \mathrm{g}^{-1}\right)\end{array}$ & $5.99 \pm 0.10^{\mathrm{a}}$ & $6.05 \pm 0.02^{\mathrm{a}}$ \\
\hline
\end{tabular}

${ }^{a-b}$ Aynı satırda farklı harflerle gösterilen değerler istatistiksel olarak birbirinden farklıdır $(P<0.05)$.

${ }^{*}$ Farka göre bulunmuştur.

Koyun ve inek türlerine ait bir çalışmada sütlerin sırasıyla yağ oranı \%5.95, \%3.45, toplam kuru madde \%17.06, \%12.61, laktoz \%4.71, \%4.79, kül $\% 0.84$, \%0.65 olduğu tespit edilmiştir (Atasoy, 2008). Diyarbakır'da satışa sunulan çiğ koyun sütleri üzerine yapılan çalışmada minimum maksimum yağ oranları \%4.42-\%15,93, yağsız kurumadde \%9.49-\%16.29, protein \%3.66-\%7.11, laktoz \%3.47-\%8.92, pH 6.30-6.90 arasında belirlenmiştir (Çelik, 2008). Yoğurt üretiminde çiğ inek sütü kullanılarak yapılan çalışmada kurumadde $\% 10.40$, yağ $\% 4.63$, protein $\% 4.25$ ve laktoz \%5.40 olarak belirlenmiştir (Karakuş ve ark., 2019). Koyun ve inek sütü kullanılarak kefir üretiminin gerçekleştirildiği çalışmada koyun ve inek çiğ sütlerinin sırasıyla kurumadde \%17.63, 
\%11.55; yağ \%6.65, \%2.67; protein \%5.49, \%2.93; titrasyon asitliği (\%L.A.) \%0.22, \%0.15 olduğu tespit edilmiştir (Arda, 2020). Bu çalışmada kullanılan çiğ süt bileşimlerinin yapılan diğer çalışmalarla paralel olduğu saptanmıştır (Atasoy, 2008; Çelik, 2008; Arda, 2020; Karakuş ve ark., 2019). Çiğ koyun sütü üzerine yapılan çalışmada Koliform bakteri sayısı $1.78 \mathrm{log}$ kob/g, $6.72 \mathrm{log}$ kob/g, E.coli sayısı $1.00 \mathrm{log}$ kob/g, 6.91 log kob/g olarak belirlenmiştir (Çelik, 2008). Çalışmada kullanılan çiğ sütlere ait mikrobiyolojik kriterlerin yapılan diğer çalışmalarla paralel olduğu gözlemlenmiştir (Çelik, 2008). Koyun ve inek sütlerinden üretilen yoğurtların özellikleri Tablo 2.'de sunulmuştur. İnek yoğurtlarının toplam kuru madde, yağ ve titrasyon asitliği değerlerinin koyun yoğurdundan düşük olduğu belirlenmiştir $(\mathrm{P}<0.05)$. $\mathrm{pH}$ değerinin ise istatistiksel olarak aynı olduğu saptanmıştır $(P>0.05)$. Ayrıca çalışmada kullanılan yoğurtlarda E.coli ve Koliform bakteri grubuna rastlanmamıştır. Türk Gıda Kodeksi Fermente Süt Ürünleri Tebliği'ne göre süt proteini en az \%3 ve titrasyon asitliği en az 0.6 en fazla 0.15 olması gerektiği bildirilmiştir (Anonim, 2009). Türk Gıda Kodeksi yoğurt mikrobiyolojik kriterleri için limit E.coli<3 kob g-ml1 , Koliform bakteri 9 kob g-mll ${ }^{-1}$ olması gerekmektedir (Anonim, 2011). Çalışmada kullanılan koyun ve inek sütlerine ait fiziksel ve mikrobiyolojik özelliklerin tebliğe uygun olduğu belirlenmiştir.

Çizelge 2. Koyun ve inek sütlerinden üretilen yoğurtların özellikleri

Table 2. Properties of yoghurts produced from sheep's and cow's milk

\begin{tabular}{|c|c|c|}
\hline $\begin{array}{l}\text { Analizler } \\
\text { Analyzes }\end{array}$ & $\begin{array}{l}\text { Koyun } \\
\text { Sheep }\end{array}$ & $\begin{array}{l}\text { İnek } \\
\text { Cow }\end{array}$ \\
\hline $\begin{array}{l}\text { Kurumadde }\left({\left.\mathrm{g} 100 \mathrm{~g}^{-1}\right)} \text { Dry matter }\left(\mathrm{g} 100 \mathrm{~g}^{-1}\right)\right.\end{array}$ & $18.00 \pm 0.26^{\mathrm{a}}$ & $12.65 \pm 0.08^{b}$ \\
\hline $\begin{array}{l}\text { Yağ }\left(\mathrm{g} 100 \mathrm{~g}^{-1}\right) \\
\text { Fat }\left(\mathrm{g} 100 \mathrm{~g}^{-1}\right)\end{array}$ & $6.96 \pm 0.15^{\mathrm{a}}$ & $3.64 \pm 0.10^{b}$ \\
\hline $\begin{array}{l}\mathrm{pH} \\
\mathrm{pH}\end{array}$ & $4.03 \pm 0.02^{\mathrm{a}}$ & $4.00 \pm 0.03^{a}$ \\
\hline $\begin{array}{l}\text { Titrasyon asitliği (\% laktik asit) } \\
\text { Titratable acidity (lactic acid \%) }\end{array}$ & $2.33 \pm 0.05^{\mathrm{a}}$ & $1.33 \pm 0.00^{b}$ \\
\hline $\begin{array}{l}\text { Escherichia coli }\left(\log \mathrm{kob} \mathrm{g}^{-1}\right) \\
\text { Escherichia coli }\left(\log \mathrm{cfu} \mathrm{g} \mathrm{g}^{-1}\right)\end{array}$ & $<1$ & $<1$ \\
\hline $\begin{array}{l}\text { Koliform bakteri }\left(\log \mathrm{kob} \mathrm{g}^{-1}\right) \\
\text { Coliform bacteria }\left(\log \mathrm{cfu} \mathrm{g}^{-1}\right)\end{array}$ & $<1$ & $<1$ \\
\hline
\end{tabular}

${ }^{a-b}$ Aynı satırda farklı harflerle gösterilen değerler istatistiksel olarak birbirinden farklıdır $(P<0.05)$.

Koyun ve inek sütünden yapılan yoğurtların sırasıyla toplam kurumadde $\% 18.66, \% 12.25$, yağ $\% 5.78, \% 3.50, \mathrm{pH} 4.67,4.56$ ve titrasyon asitliği $\% 0.94, \% 0.70$ olarak bulunmuştur (Vianne et al., 2017). Başka bir çalışmada koyun ve inek yoğurtlarının kurumadde, yağ, $\mathrm{pH}$ ve titrasyon asitliği değerleri sırasıyla \%18.59, \%12.12; \%6.66, $\% 3.91 ; 4.16,4.05$ ve \%1.52, \%1.01 olarak belirlenmiştir (Erkaya ve Şengül, 2012). Araştırmada elde edilen yoğurt değerleri daha önceki çalışmalarla benzerlik göstermektedir (Vianne et al., 2017; Erkaya ve Şengül, 2012).

Koyun ve inek sütlerinden elde edilen çiğ krema, olgunlaştırılmış ve pastörize edilmiş kremaya ait kurumadde, yağ, pH, titrasyon asitliği, E.coli ve Koliform bakteri değerleri Şekil 4.'te gösterilmiştir. En yüksek kurumadde ve yağ değerleri koyun pastörize kremasında, en düşük kurumadde ve yağ değeri ise inek olgunlaştırılmış kremada saptanmıştır. pH en yüksek çiğ koyun kremasında, en düşük olgunlaştırılmış inek kremasında belirlenmiştir. Titrasyon asitliği değerleri incelendiğinde ise en düşük değer koyun çiğ kremasında, en yüksek değer ise koyun olgunlaştırılmış kremada tespit edilmiştir. Süt türünün kuru madde ve yağ, krema faktörünün ise $\mathrm{pH}$, titrasyon asitliği üzerine etkili olduğu saptanmıştır $(P<0.001)$. 
Çizelge 3. Koyun ve İnek sütünden üretilen kremaların fizikokimyasal özellikleri

Table 3. Physicochemical properties of creams produced from sheep's and cow's milk

\begin{tabular}{|c|c|c|c|c|c|c|c|c|}
\hline \multirow{2}{*}{$\begin{array}{l}\text { Analizler } \\
\text { Analyzes }\end{array}$} & \multicolumn{2}{|c|}{$\begin{array}{l}\text { Çiğ Krema } \\
\text { Raw cream }\end{array}$} & \multicolumn{2}{|c|}{$\begin{array}{c}\text { Olgunlaştırılmış Krema } \\
\text { Ripening cream }\end{array}$} & \multicolumn{2}{|c|}{$\begin{array}{l}\text { Pastörize Krema } \\
\text { Pasteurized cream }\end{array}$} & \multirow{2}{*}{$\begin{array}{l}\mathrm{ST} \\
M \\
T\end{array}$} & \multirow{2}{*}{$\begin{array}{l}\mathrm{KF} \\
\mathrm{CF}\end{array}$} \\
\hline & $\begin{array}{l}\text { Koyun } \\
\text { Sheep }\end{array}$ & $\begin{array}{l}\text { İnek } \\
\text { Cow }\end{array}$ & $\begin{array}{l}\text { Koyun } \\
\text { Sheep }\end{array}$ & $\begin{array}{l}\text { İnek } \\
\text { Cow }\end{array}$ & $\begin{array}{l}\text { Koyun } \\
\text { Sheep }\end{array}$ & $\begin{array}{l}\text { İnek } \\
\text { Cow }\end{array}$ & & \\
\hline $\begin{array}{l}\text { Kurumadde }\left(\mathrm{g} 100 \mathrm{~g}^{-1}\right) \\
\text { Dry matter }\left(\mathrm{g} 100 \mathrm{~g}^{-1}\right)\end{array}$ & $48.53 \pm 0.05^{b}$ & $43.27 \pm 0.18^{d}$ & $\begin{array}{l}48.29 \pm 0.2 \\
1^{b}\end{array}$ & $42.65 \pm 0.20^{e}$ & $52.20 \pm 0.14^{a}$ & $44.22 \pm 0.10^{c}$ & $* * *$ & ns \\
\hline 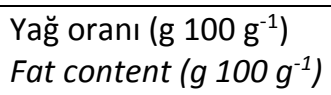 & $37.35 \pm 0.25^{a}$ & $36.40 \pm 0.20^{b}$ & $\begin{array}{l}37.35 \pm 0.2 \\
5^{\mathrm{a}}\end{array}$ & $36.40 \pm 0.20^{b}$ & $37.60 \pm 0.20^{a}$ & $36.55 \pm 0.10^{b}$ & $* * *$ & ns \\
\hline $\begin{array}{l}\mathrm{pH} \\
\mathrm{pH}\end{array}$ & $6.63 \pm 0.07^{a}$ & $6.58 \pm 0.05^{a}$ & $5.33 \pm 0.03^{b}$ & $5.30 \pm 0.02^{b}$ & $5.32 \pm 0.04^{b}$ & $5.31 \pm 0.01^{b}$ & ns & *** \\
\hline $\begin{array}{l}\text { Titrasyon asitliği (\% } \\
\text { laktik asit) } \\
\text { Titratable acidity } \\
\text { (lactic acid \%) }\end{array}$ & $0.15 \pm 0.01^{\mathrm{e}}$ & $0.25 \pm 0.00^{d}$ & $0.57 \pm 0.01^{a}$ & $0.50 \pm 0.00^{b}$ & $0.47 \pm 0.00^{c}$ & $0.45 \pm 0.01^{c}$ & ns & $* * *$ \\
\hline $\begin{array}{l}\text { E.coli } \\
\left(\log k_{0 b} g^{-1}\right) \\
\text { E.coli }\left(\log c f u g^{-1}\right)\end{array}$ & $4.24 \pm 0.16^{b}$ & $5.64 \pm 0.23^{a}$ & $4.73 \pm 0.13^{b}$ & $6.05 \pm 0.18^{a}$ & $<1^{\mathrm{c}}$ & $<1^{\mathrm{c}}$ & ns & *** \\
\hline $\begin{array}{l}\text { Koliform bakteri } \\
\text { (log kob } \mathrm{g}^{-1} \text { ) } \\
\text { Coliform bacteria (log } \\
\text { cfu } \mathrm{g}^{-1} \text { ) }\end{array}$ & $5.21 \pm 0.21^{b c}$ & $5.56 \pm 0.21^{c}$ & $\begin{array}{l}6.07 \pm 0.19^{a} \\
b\end{array}$ & $6.32 \pm 0.06^{a}$ & $<1^{d}$ & $<1^{d}$ & ns & *** \\
\hline
\end{tabular}

$(P<0.05) ; *: P<0.05 ;^{* *}: P<0.01 ;^{* * *}: P<0.001$ düzeyinde önem; ST: Süt türü (Koyun ve inek); KF: Krema Faktörü (çiğ, olgunlaştırılmış ve pastörize krema); MT: milk type; CF: cream factor; ns: önemsiz.

Türk Gıda Kodeksi Krema ve Kaymak Tebliği'ne göre kremalar süt yağı oranına göre üç gruba ayrılmıştır. 'Az yağlı krema' süt yağı oranı en az $\% 10$, 'Krema' süt yağı oranı en az $\% 18$, 'Tam yağı krema' ise süt yağı oranı en az \%45 olan krema olarak tanımlanmıştır (Anonim, 2003). Tebliğe göre bu çalışmada kullanılan krema içerdiği süt yağı oranına göre 'krema' kategorisinde yer almaktadır. Ayrıca tebliğde titrasyon asitliği değerinin laktik asit cinsinden \%0.225'ten fazla olmaması gerektiği bildirilmiştir (Anonim, 2003). Koyun çiğ kremasının titrasyon asitliği değerinin tebliğe uyduğu, inek çiğ kremasının ise tebliğde belirtilen değerden daha yüksek olduğu tespit edilmiştir.

E.coli ve Koliform bakteri sayıları incelendiğinde en düşük E.coli ve Koliform bakteri sayıları pastörize kremalarda (<1), en yüksek inek olgunlaştırılmış kremada olduğu belirlenmiştir (Şekil 4). E.coli ve Koliform bakteri sayıları üzerine süt türü etkisiz $(P>0.05)$, krema faktörü etkili olmuştur $\quad(\mathrm{P}<0.001)$. Türk Gıda Kodeksi Mikrobiyolojik Kriterler Tebliğinde pastörize krema için belirlenen E.coli limit değeri $<3 \mathrm{kob} \mathrm{g}_{-} \mathrm{ml}^{-1}$ olarak belirlenmiştir (Anonim, 2011). Pastörize kremaların mikrobiyolojik kriterlerinin tebliğe uygun olduğu görülmüştür.

Süt, yoğurt ve kremalara ait kuru madde ve yağ değerleri Şekil 2. 'de gösterilmiştir. Buna göre en yüksek kuru madde ve yağ değerleri koyun sütü pastörize kremada (KPK), en düşük değer ise inek çiğ sütünde (IÇS) tespit edilmiştir $(P<0.05)$. Kremaların kuru madde ve yağ değerlerinin süt ve yoğurtlardan daha yüksek olduğu belirlenmiştir. Bu durumun; kremaların yağ oranının $\% 37 \pm 2$ olarak standardize edilmesinden kaynaklandığı düşünülmektedir. Süt ve yoğurdun kuru madde ve yağ değerlerinin aynı olduğu saptanmıştır $(P>0.05)$. Bunun nedeninin sütün yoğurda işlenmesinde bileşim açısından değişim olmamasından ileri geldiği tahmin edilmektedir. 


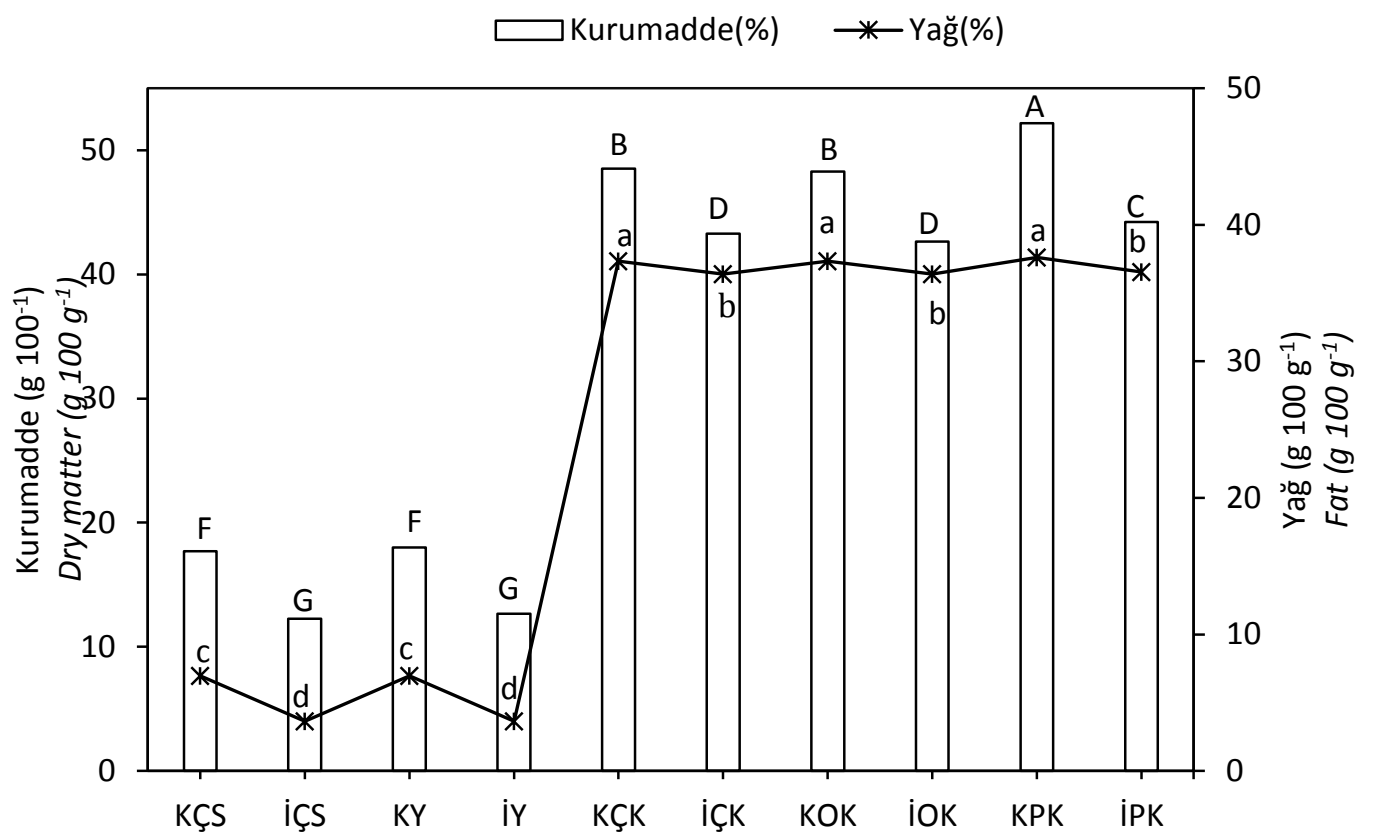

Şekil 2. Örneklere ait kurumadde ve yağ değerleri

Figure 2. Dry matter and oil values of the samples

Grafikte gösterilen büyük harfler kurumadde değerleri, küçük harfler ise yağ değerleri arasındaki istatistiksel farkı göstermektedir ( $\mathrm{P}<0.05)$. KÇS: Koyun çiğ süt; IÇS: İnek çiğ süt; KY: Koyun yoğurt; IY: İnek yoğurt; KÇK: Koyun çiğ krema; içK: Inek çiğ krema; KOK: Koyun olgunlaştırılmış krema; iOK: İnek olgunlaştırılmış krema; KPK: Koyun pastörize krema; IPK: İnek pastörize krema.

Bu çalışmada analiz edilen örneklere ait $\mathrm{pH}$ ve titrasyon asitliği değerleri Şekil 3.'te gösterilmiştir. En yüksek pH değeri koyun çiğ sütünde (KÇS), en düşük $\mathrm{pH}$ değerleri ise koyun ve inek yoğurtlarında (KY ve iY) gözlemlenmiştir $P<0.05)$. Sütlerden yoğurt üretimi aşamasında $\mathrm{pH}$ değerinde düşme, titrasyon asitliğinde artma görülmüştür. Bu durumun starter bakterilerin aktivitesine ve laktozun laktik asit bakterileri tarafından fermantasyonuna bağlı olduğu düşünülmektedir (Tamime and Robinson, 1999). Koyun sütü sahip olduğu yüksek protein, mineral madde ve yüksek tamponlama kapasitesi nedeniyle daha fazla asit üretebilme yeteneğine sahiptir. $\mathrm{Bu}$ durumun koyun yoğurdu asitliğinin yüksek olmasına neden olduğu düşünülmektedir (Atasoy, 2008; Urbach 1995).

İnek çiğ kremasının titrasyon asitliği değeri koyun kremasından daha yüksek bulunmuştur $(P<0.05)$. Bu durum koyun sütünün sahip olduğu yüksek mineral ve protein içeriğine bağlı tamponlama özelliğinden ileri geldiği tahmin edilmektedir. Sağımdan sonra koyun sütü sahip olduğu yüksek tamponlama kapasitesi sayesinde asitlik gelişimine karşı daha dirençlidir (Luquet, 1985). Koyun sütünün doğal asitliği diğer türlere nazaran daha yüksek olup sonradan gelişen asitlik yavaş gelişmektedir (Metin, 2017). Kremanın olgunlaştırılması daha iyi yayıklanabilme, tereyağının raf ömrünün uzatılması ve istenen tataromaya sahip olmak için yapılmaktadır. Laktik asit bakterileri tarafından laktozun fermantasyonu ile olgunlaştırma gerçekleştirilmektedir (Oysun ve Gönç, 1993). Olgunlaştırılmış kremaların pH: 4.55.4 aralığında olduğu bildirilmiştir (Atamer, 2016). Çiğ kremaların doğal yollarla olgunlaştırıması aşamasında $\mathrm{pH}$ değerinde düşüş, titrasyon asitliği değerinde artış gözlemlenmiştir. Pastörizasyon aşamasından sonra $\mathrm{pH}$ ve titrasyon asitliği değerlerinin değişmediği tespit edilmiştir $(P>0.05)$. 


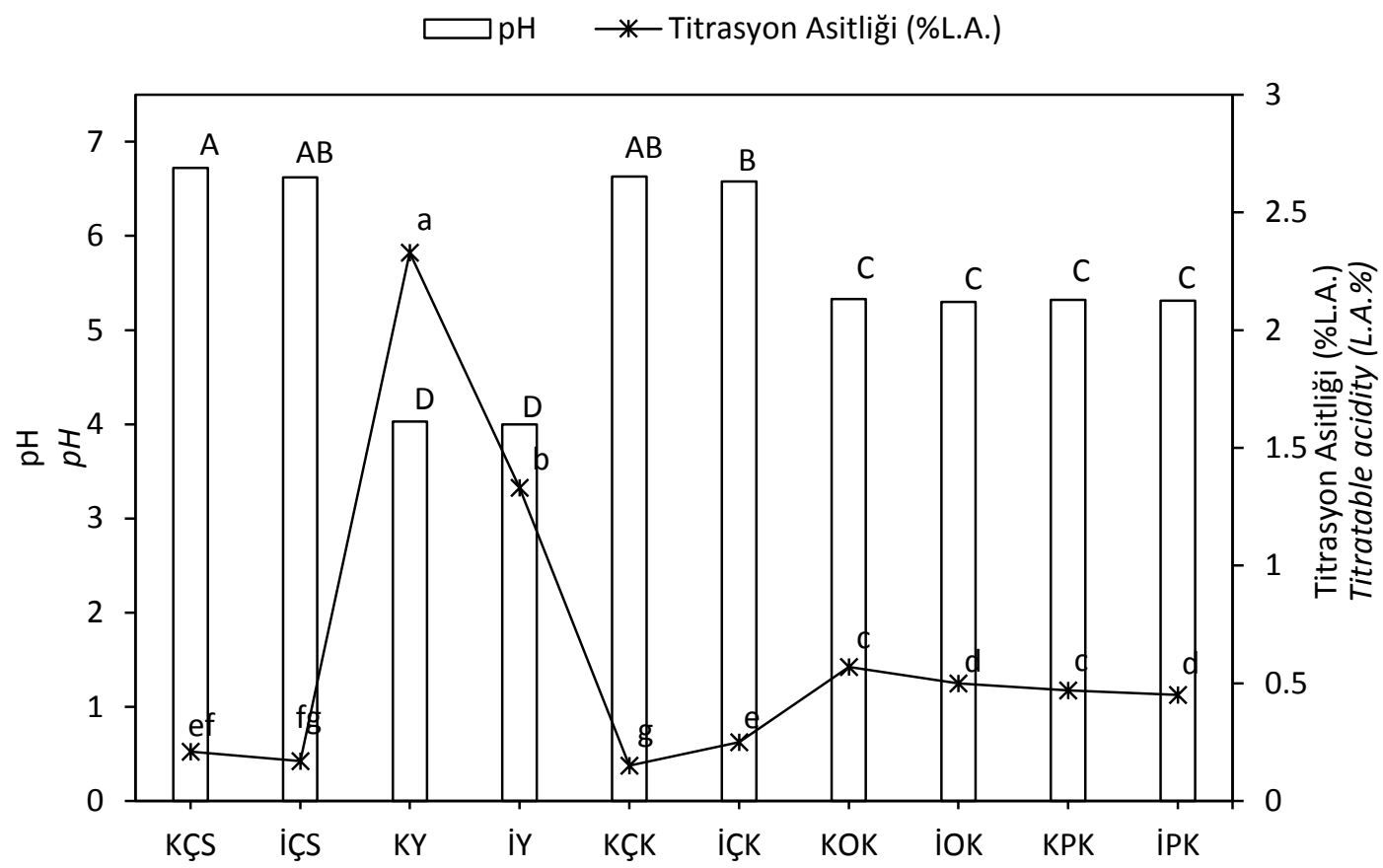

Şekil 3. Örneklere ait $\mathrm{pH}$ ve titrasyon asitliği değerleri

Figure 3. $\mathrm{pH}$ and titratable acidity values of the samples

Grafikte gösterilen büyük harfler pH değerleri, küçük harfler ise titrasyon asitliği değerleri arasındaki istatistiksel farkı göstermektedir ( $P<0.05)$. KÇS: Koyun çiğ süt; içS: İnek çiğ süt; KY: Koyun yoğurt; iY: Inek yoğurt; KÇK: Koyun çiğ krema; IÇK: İnek çiğ krema; KOK: Koyun olgunlaştırılmış krema; iOK: İnek olgunlaştırılmış krema; KPK: Koyun pastörize krema; IPK: Inek pastörize krem.

Üretimde kullanılan tüm örneklere ait mikrobiyolojik ekim sonuçları Şekil 3.'te gösterilmiştir. En yüksek E.coli ve Koliform bakteri değerleri iOK'da tespit edilmiştir. KY, IY, KPK ve IPK'da E.coli ve Koliform bakteriye rastlanmamıştır $(P>0.05)$. Çiğ sütlerde E.coli ve Koliform grubu bakterilerin inek sütlerinde daha yüksek olduğu tespit edilmiştir. Çiğ kremaların olgunlaştırılması ile mikroorganizma aktiviteleri devam ettiği için E.coli ve Koliform bakteri sayılarında artış saptanmıştır. Çiğ sütlere ve olgunlaştırılmış kremalara ısıl işlem uygulanarak elde edilen yoğurtlarda ve pastörize kremalarda E.coli ve Koliform bakteriler inaktif hale getirilmiştir. Çiğ süt patojen ve birçok zararlı mikroorganizma için besleyici bir ortama sahiptir. Bu yüzden birçok bakteri gelişebilmekte ve çoğalabilmektedir. Çiğ sütte çok sayıda gram pozitif ve negatif bakteriler, patojenler, bozulma yapan bakteriler ve hayvan hastalığına neden olan mikroorganizmalar bulunmaktadır (Villamiel and de Jong, 2000). Sütte patojen ve Koliform bakterilerin tespiti hayvanın memesinden, beslenmeden, sağım kaplarından, hijyenik olmayan koşullardan kaynaklı kontaminasyonun bir göstergesidir (Altalhi and Hassan, 2009). Pastörize edilmemiş kremalarda Streptococcus agalactiae, Streptococcus pyogenes, Staphylococcus aureus ve Brucella abortus canlılıklarını sürdürürler ve tereyağına nüfuz ederler. Bu yüzden kremaların pastörize edilerek bu mikroorganizmaların yok edilmesi gerektiği bildirilmiştir (Budhkar et al., 2014). 


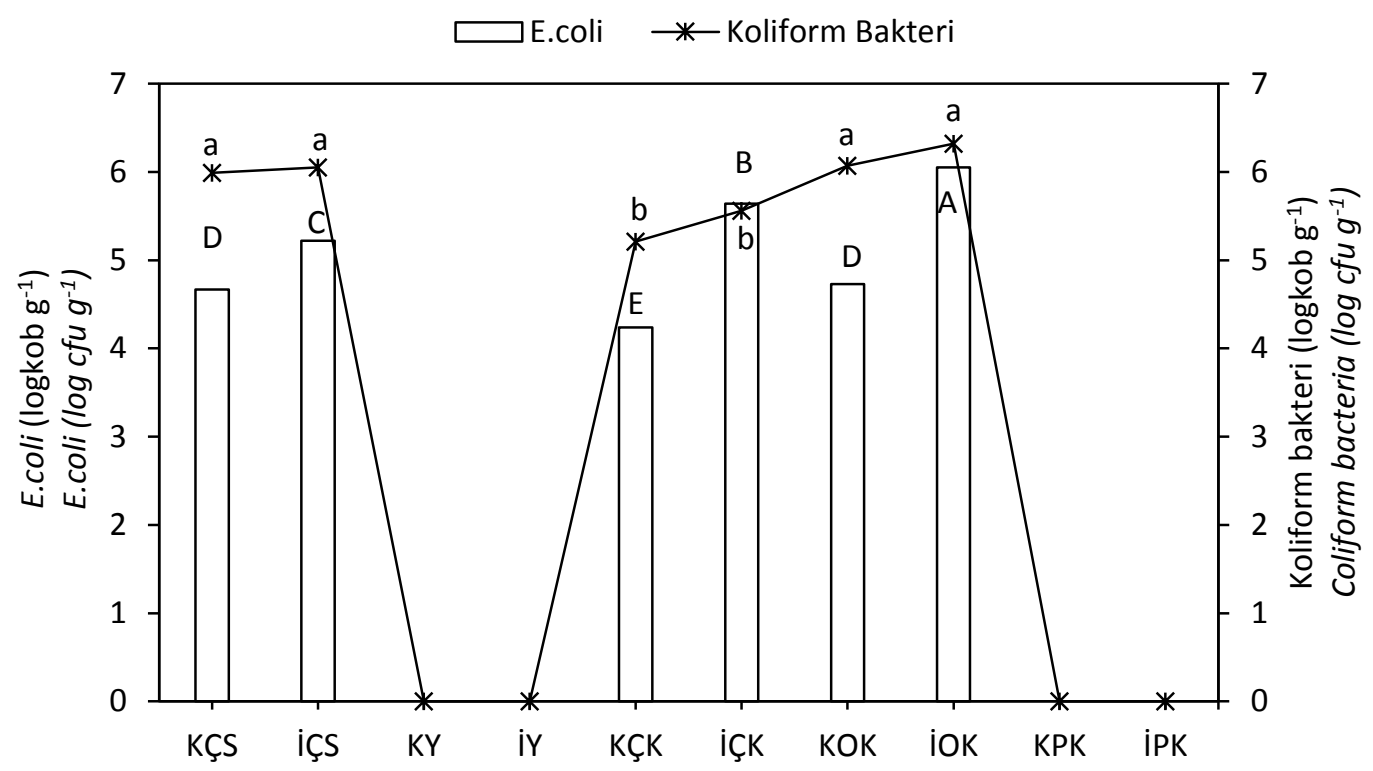

Şekil 4: Örneklere ait mikrobiyolojik özellikler Figure 4. Microbiological properties of the samples Grafikte gösterilen büyük harfler E.coli değerleri, küçük harfler ise Koliform bakteri değerleri arasındaki istatistiksel farkı göstermektedir $(P<0.05)$. KÇS: Koyun çiğ süt; içS: İnek çiğ süt; KY: Koyun yoğurt; iY: İnek yoğurt; KÇK: Koyun çiğ krema; IÇK: İnek çiğ krema; KOK: Koyun olgunlaştırılmış krema; IOK: İnek olgunlaştırılmış krema; KPK: Koyun pastörize krema; IPK: İnek pastörize krema.

\section{Sonuçlar}

Yapılan çalışmada kullanılan süt, yoğurt ve kremaların fiziksel ve mikrobiyolojik yönden incelemesi yapılmıştır. Araştırmada kullanılan çiğ koyun ve inek sütlerinin A sınıfı kategorisinde yer aldığı belirlenmiştir. Çiğ süt, yoğurt ve kremaların fizikokimyasal ve mikrobiyolojik olarak Türk Gıda Kodeksi'ne uygun olduğu saptanmıştır. Çalışma sonucunda sadeyağ üretiminde kullanılan yoğurtların ve pastörize kremanın gıda güvenliği kriterlerini sağladığı tespit edilmiştir.

\section{Ekler}

Bu çalışma, Mehmet şükrü KARAKUŞ’un Doktora Tezinin bir kısmından yararlanarak hazırlanmıştır.

Bu çalışmayı 19247 nolu proje ile destekleyen Harran Üniversitesi Bilimsel Araştırmalar (HÜBAP) Birimi'ne teşekkür ederiz.

Bu çalışmayı 10001 nolu proje (GAP-URFA YAĞı) ile destekleyen Türkiye Cumhuriyeti Sanayi ve Teknoloji Bakanlığı ile Güneydoğu Anadolu Projesi Bölge Kalkınma İdaresi Başkanlığı'na teşekkür ederiz.
Çıkar Çatışması Beyanı: Makale yazarları aralarında herhangi bir çıkar çatışması olmadığını beyan ederler.

Yazar Katkısı: Ahmet Ferit Atasoy araştırmanın tasarlanmasında, Mehmet Şükrü Karakuş, Zahide Polat ve Sevda Kamacı üretimin gerçekleştirilmesi ve deneysel çalışmaların yürütülmesinde, Mehmet Şükrü Karakuş verilerin analiz edilmesinde ve makale yazımında katkıda bulunmuşlardır. Yazarlar makalenin son halini okumuş ve onaylamışlardır.

\section{Kaynaklar}

Ali, A. A. \& Fischer, R. M. (2005). Implementation of HACCP to bulk cream and butter production line. Food Reviews International, 21(2), 189-210. https://doi.org/10.1080/FRI-200051878.

Altalhi, A. D., \& Hassan, S. A. (2009). Bacterial quality of raw milk investigated by Escherichia coli and isolates analysis for specific virulence-gene markers. Food Control, 20(10), 913-917. https://doi.org/10.1016/j.foodcont.2009.01.05.

Anonim (2003). Türk Gıda Kodeksi Krema ve Kaymak Tebligi 2003/34. Retrieved from: https://www.resmigazete.gov.tr/eskiler/2003/09/20 030927.htm\#7. Erişim tarihi:17.08.2021.

Anonim (2005). Tereyağı, Diğer Süt Yağı Esaslı Sürülebilir Ürünler ve Sadeyağ Tebligi 2005/19. Retrieved from: 
https://www.resmigazete.gov.tr/eskiler/2005/04/20 050412-11.htm. Erişim tarihi:17.08.2021.

Anonim (2009). Fermente Süt Ürünleri Tebligi 2009/25. Retrieved from:

https://www.resmigazete.gov.tr/eskiler/2009/02/20 090216-8.htm. Erişim tarihi: 17.08.2021.

Anonim (2018). Şanlıurfa Sadeyağı (Urfa Yağı). Retrieved from:

https://www.turkpatent.gov.tr/TURKPATENT/geogra phicalRegisteredList/. Erişim tarihi: 17.08.2021.

Anonim (2019a). Çiğ inek sütünün sınıflandırılmasına ilişkin tebliğ 2019/64. Retrieved from: https://www.resmigazete.gov.tr/eskiler/2020/01/20 200125-41.htm. Erişim tarihi: 17.08.2021.

Anonim (2019b). İçme Sütleri Tebliği 2019/12. Retrieved from:

https://www.resmigazete.gov.tr/eskiler/2019/02/20 190227-5.htm. Erişim tarihi: 17.08.2021.

Arda, B. (2020). Inek ve Koyun sütünden dane veya kültür kullanılarak üretilen kefirlerin yağ asidi profili. Yüksek Lisans Tezi, Fen Bilimleri Enstitüsü, Ege Üniversitesi. Izmir, 83s.

Atamer, M. (2016). Tereyağı Teknolojisi. Sidas Medya, İzmir.

Atasoy, A. F. (2008). Evaluation of $\mathrm{pH}$ change kinetics during different stages of Kashar cheese production from bovine, ovine and caprine milk. Journal of food processing preservation, 32(3), 416-428. https://doi.org/10.1111/j.1745-4549.2008.00187.x.

Budhkar, Y., Bankar, S., \& Singhal, R. (2014). Milk and milk products: microbiology of cream and butter. In Encyclopedia of Food Microbiology: Second Edition (pp. 728-737). https://doi.org/10.1016/B978-0-12384730-0.00221-4.

Çelik, M. N. (2018). Diyarbakır Bölgesinde satışa sunulan çiğ koyun sütlerinin mikrobiyolojik, fiziko-kimyasal ve organoleptik özelliklerinin araştırılması. Yüksek Lisans Tezi, Sağlık Bilimleri Enstitüsü, Dicle Üniversitesi, Diyarbakır, 48s.

Erkaya, T., \& Şengül, M. (2012). A Comparative Study on Some Quality Properties and Mineral Contents of Yoghurts Produced From Different Type of Milks. Kafkas Universitesi Veteriner Fakultesi Dergisi, 18(2). https://doi.org/10.9775/kvfd.2011.5498.

Haenlein, G. (2001). Past, present, and future perspectives of small ruminant dairy research. Journal of dairy science, $\quad$ 84(9), 2097-2115. https://doi.org/10.3168/jds.S0022-0302(01)74655-3.

Halkman, A. K. (2005). Gıda Mikrobiyolojisi Uygulamaları. MERCK.

Karakuş, M. Ş., Kırmacı, H. A., \& Atasoy, A. F. (2019). Stevia Özü İlavesinin Çilek Aromalı Acidophilus-Bifidus
Yoğurtların Bazı Fizikokimyasal ve Duyusal Özellikleri Üzerine Etkileri. Harran Üniversitesi Mühendislik Dergisi, 4(2), 59-68.

Metin, M. (2017). Süt Teknolojisi. Sütün Bileşimi ve Işslenmesi. Ege Üniversitesi Basımevi, İzmir.

Oysun, G., \& Gönç, S. (1993). Tereyağına İşlenecek Kremaya Uygulanacak İşlemler. Gıda, 18(5), 333-338.

Paçacı, G. (2019). Dünya'da ve Türkiye'de iklim değişikliği kaynaklı Gıda Güvenliği sorunu. Yüksek Lisans Tezi, Sosyal Bilimler Enstitüsü, Kocaeli Üniversitesi, Kocaeli, $137 \mathrm{~s}$

Pulina, G., Nudda, A., Battacone, G., \& Cannas, A. J. (2006). Effects of nutrition on the contents of fat, protein, somatic cells, aromatic compounds, and undesirable substances in sheep milk. Animal Feed Science Technology, 131(3-4), 255-291. https://doi.org/10.1016/j.anifeedsci.2006.05.023

Şanlıdere Aloğlu, H. (2018). Süt ve Süt Ürünleri Analiz Yöntemleri. Sidas Yayınları, İzmir.

Tamime, A. Y., \& Robinson, R. K. (1999). Yoghurt: science and technology. Woodhead Publishing.

Urbach, G. (1995). Contribution of lactic acid bacteria to flavour compound formation in dairy products. International Dairy Journal, 5(8), 877-903. https://doi.org/10.1016/0958-6946(95)00037-2.

Van Schothorst, M., \& Kleiss, T. (1994). HACCP in the dairy industry. Food Control, 5(3), 162-166. https://doi.org/10.1016/0956-7135(94)90076-0

Vianna, F. S., Canto, A. C., da Costa-Lima, B. R., Salim, A. P. A., Costa, M. P., Balthazar, C. F., Oliveira, B. R., Rachid, R. P., Franco, R. M., \& Conte-Junior, C. A. (2017). Development of new probiotic yoghurt with a mixture of cow and sheep milk: effects on physicochemical, textural and sensory analysis. Small Ruminant Research, 149, 154-162. https://doi.org/10.1016/j.smallrumres.2017.02.013.

Villamiel, M., \& de Jong, P. J. (2000). Inactivation of Pseudomonas fluorescens and Streptococcus thermophilus in Trypticase $^{\circledR}$ Soy Broth and total bacteria in milk by continuous-flow ultrasonic treatment and conventional heating. Journal of food engineering, 45(3), 171-179. https://doi.org/10.1016/S0260-8774(00)00059-5.

Yıldız Akgül, F., Atasoy, A. F., \& Yetişemiyen, A. (2018). Süt ve Süt Ürünleri Analiz Yöntemleri. Sidas Yayınları, İzmir.

Yokuş, D., Karakuş, M. Ş., \& Atasoy, A. F. (2019). Koyun ve inek sütlerinden üretilen Şanlıurfa Sadeyağlarının fiziksel, kimyasal ve mikrobiyolojik özelliklerinin belirlenmesi. Harran Tarım ve Gıda Bilimleri Dergisi, 23(4), 463-476. https://doi.org/10.29050/harranziraat.538220. 